\title{
Lutowanie miękkie kompozytu grafitowego ze stopem aluminiowym PA38
}

\section{Soldering of graphite composite with PA38 aluminum alloy}

\section{Streszczenie}

W artykule przedstawiono problematykę dotyczącą lutowania miękkiego kompozytu grafitowego ze stopem aluminium PA38. Połączenia tego typu znajdują zastosowanie w urządzeniach przesyłających energię elektryczną, w związku z czym muszą charakteryzować się dobrą przewodnością elektryczną. Wykonano próbne złącza lutowane z zastosowaniem warstwy pośredniej $\mathrm{Cu}$, naniesionej galwanicznie na powierzchnię kompozytu grafitowego. Przedstawiono wyniki badań wytrzymałościowych oraz badań metalograficznych przy użyciu mikroskopii świetlnej.

Słowa kluczowe: kompozyt grafitowy; lutowanie miękkie; warstwy pośrednie $\mathrm{Cu}$; stop aluminium PA38

\section{Abstract}

The problems concerning soldering of graphite composite with aluminum alloy PA38, were presented in the article. This type of joints are used in devices transmitting electricity therefore, it must have a good electrical conductivity. Made test soldered joints using an intermediate layer of Cu-plated applied to the surface of the graphite composite. The results of research strength and metallographic examination using light microscopy, were presented.

Keywords: graphite composite; soldering; $\mathrm{Cu}$ intermediate layers; aluminum alloy PA38

\section{Wstęp}

Spajanie materiałów, szczególnie takich jak grafit i materiały kompozytowe na bazie grafitu z metalami, stanowi zwykle duży problem technologiczny. Połączenia materiałów o budowie kompozytowej na bazie grafitu $z$ aluminium i jego stopami występują często w urządzeniach przewodzących prąd elektryczny, dlatego złącza takie muszą cechować się odpowiednią przewodnością elektryczną i wytrzymałością mechaniczną. Możliwe jest ich klejenie, jednakże połączenia te nie są w stanie zapewnić wymaganej przewodności elektrycznej, nawet w przypadku zastosowania klejów o budowie kompozytowej z użyciem napełniaczy proszkowych lub siatek miedzianych. Dobrą przewodność elektryczną można natomiast osiągnąć stosując połączenie metaliczne uzyskane w procesie lutowania miękkiego. Lutowanie grafitu w sposób bezpośredni z metalami jest jednak niemożliwe do wykonania z uwagi na brak jego zwilżalności lutami miękkimi.

W celu wykonania połączeń lutowanych o dobrych właściwościach eksploatacyjnych, niezbędne jest zastosowanie warstw pośrednich nanoszonych na powierzchnię kompozytu grafitowego. Jedną z możliwych do zastosowania technologii nanoszenia warstw są metody galwaniczne. Zastosowanie warstw pośrednich w procesach lutowania jest znane, lutuje się tak $\mathrm{np}$. miedź $\mathrm{z}$ aluminium lub miedź ze stalą kwasoodporną 18/10 przy użyciu spoiw miedzianofosforowych $[1 \div 3]$. Na rysunku 1 pokazano przekrój elektrody grafitowej z galwanicznie naniesioną powłoką miedzianą o grubości $70 \mu \mathrm{m}$. Adhezja mechaniczna odpowiedzialna za połączenie powłoki Cu z elektrodą grafitową jest mechanizmem całkowicie wystarczającym dla tego rodzaju wyrobów. Natomiast, wszędzie tam gdzie wymagania dotyczą odpowiednio większej wytrzymałości mechanicznej połączenia powłoki Cu z podłożem grafitowym, należy dokonać aktywacji powierzchni grafitowej.

Znane są również inne metody nanoszenia warstw pośrednich do procesów lutowania, które są z powodzeniem stosowane w przemyśle samochodowym. Przykładowo lutowanie konektorów do szyb samochodowych odbywa się poprzez warstwę pośrednią w postaci srebrnej farby wypalanej na szybie. Metalowe warstwy pośrednie mogą być również nanoszone metodą niskociśnieniowego natrysku na zimno (Cold Spray) [4].

Przy wyborze odpowiedniej metody nanoszenia warstw pośrednich do procesu lutowania kompozytu grafitowego

Prof. dr hab. inż. Zbigniew Mirski; dr inż. Tomasz Wojdat; dr inż. Tomasz Piwowarczyk; dr hab. inż. Kazimierz Granat, prof. nadzw. PWr; dr inż. Wiesław Derlukiewicz; Aleksandra Jakubczyk - Politechnika Wrocławska; mgr inż. Ireneusz Ciepacz - AGA-TEC Wrocław.

Autor korespondencyjny/Corresponding author: zbigniew.mirski@pwr.edu.pl 

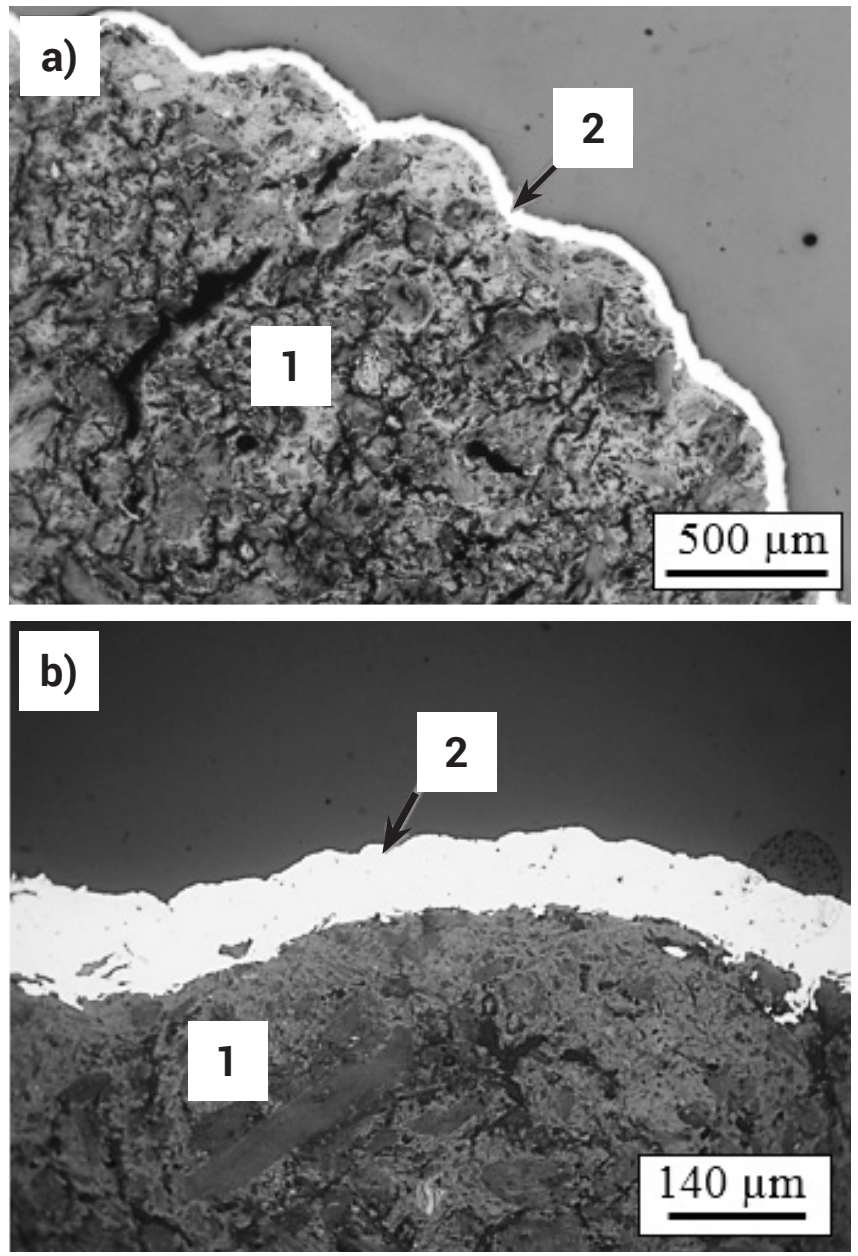

Rys. 1. Powłoka Cu (2) naniesiona galwanicznie na powierzchnię elektrody grafitowej $(1)-(a, b)$

Fig. 1. Cu coath (2) galvanically deposited on surface of a graphite electrode $(1)-(a, b)$

z aluminium PA38, należy wziąć pod uwagę głównie możliwość zapewnienia odpowiedniej przyczepności warstwy do podłoża grafitowego, ponieważ połączenia tej pary materiałów w warunkach eksploatacyjnych narażone są na naciski powierzchniowe i poddawane są naprężeniom ścinającym. Uzasadnione wydaje się tu zastosowanie powłok galwanicznych, głównie z uwagi na możliwość kontrolowanego nanoszenia nawet bardzo cienkich warstw oraz ich stosunkowo dobrą przyczepność do pokrywanych podłoży [6].

\section{Materiały do badań}

W badaniach zastosowano materiał kompozytowy (rys. 2a i 2b) na bazie koksu pakowego z dodatkiem grafitu (spełniającego funkcję smaru) i 40\% wag. ziaren Cu jako napełniacza, sklejonych żywicą wypaloną do węgla szklistego. Jest to materiał o dobrych właściwościach trybologicznych, nienasiąkliwy, o porach zamkniętych (porowatość ok. 1\%) i dużej twardości Shore'a.

Kompozyt grafitowy lutowany był do stopu aluminium PA38 (6060). Jest to stop charakteryzujący się średnią wytrzymałością na rozciąganie i średnią wytrzymałością
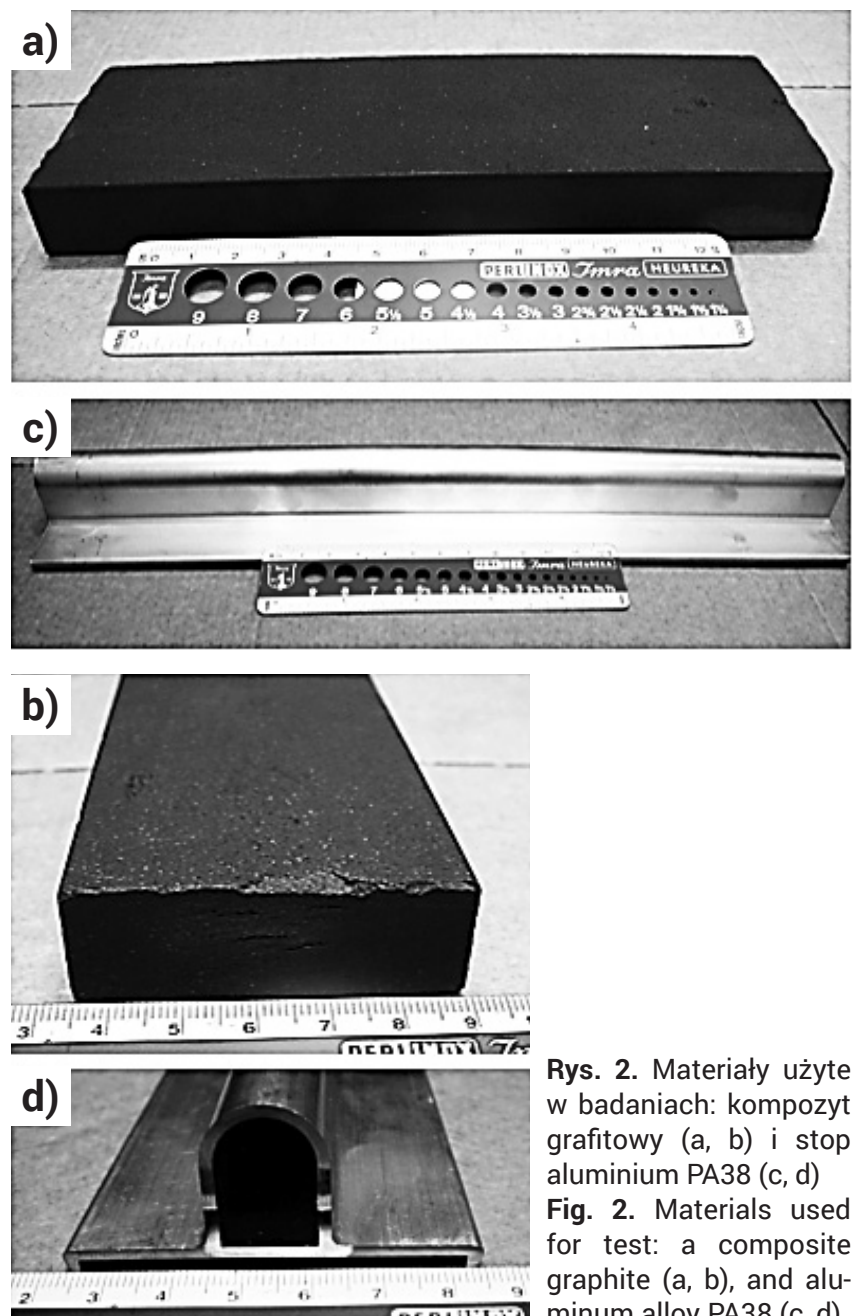

Rys. 2. Materiały użyte w badaniach: kompozyt grafitowy (a, b) i stop aluminium PA38 (c, d)

Fig. 2. Materials used for test: a composite graphite $(a, b)$, and aluminum alloy PA38 (c, d)

zmęczeniową. Został wybrany ze względu na wysoką podatność do tłoczenia umożliwiającą wykonanie z niego profili o skomplikowanym kształcie (rys. 2c i 2d). Skład chemiczny stosowanego stopu aluminium przedstawiono w tablicy I.

\section{Nanoszenie galwanicznej powłoki miedzianej na kompozyt grafitowy}

Do prób galwanicznego nakładania powłoki miedzianej na kompozyt grafitowy, wytypowano dwie kąpiele Firmy Sur-Tec GmbH (Niemcy). Kąpiel Sur-Tec 867 jest kąpielą kwaśną, natomiast kąpiel Sur-Tec 864 jest kąpielą alkaliczną - bezcyjankową. Proces nakładania powłoki na kompozyt grafitowy przebiegał według schematu zamieszczonego w tablicy II.

Po wstępnych próbach pokrywania i badaniach przyczepności, do dalszych badań wytypowano kąpiel alkaliczną Sur-Tec 864 lepiej spełniającą postawione wymagania. W trakcie prowadzonych prób, okazało się, że istotnym czynnikiem decydującym o przyczepności powłoki $\mathrm{Cu}$ do kompozytu jest sposób przygotowania jego powierzchni oraz jej rozwinięcie. Dlatego też, w celu określenia wpływu sposobu przygotowania powierzchni na przyczepność po-

Tablica I. Skład chemiczny stopu aluminium PA38 (wg PN EN 573-3:2014-02)

Table I. The chemical composition of the aluminum alloy PA38 (acc to PN EN 573-3:2014-02)

\begin{tabular}{|c|c|c|c|c|c|c|c|c|}
\hline Si & Fe & Cu & Mn & Mg & Cr & Zn & Ti & Al \\
\hline $0,3 \div 0,6$ & $0,1 \div 0,3$ & $\max 0,1$ & $\max 0,1$ & $0,35 \div 0,6$ & $\max 0,05$ & $\max 0,15$ & $\max 0,1$ & reszta \\
\hline
\end{tabular}


Tablica II. Przebieg procesów nakładania powłok galwanicznych $[7,8]$

Table II. Depositing processes of galvanic coating $[7,8]$

\begin{tabular}{|c|c|c|}
\hline Lp. & Kąpiel kwaśna Sur-Tec 867 & Kąpiel alkaliczna Sur-Tec 864 \\
\hline 1. & $\begin{array}{c}\text { odtłuszczanie ultradźwiękowe - Sur-Tec 134, } \\
\text { temperatura } 23^{\circ} \mathrm{C} \text {, czas } 180 \mathrm{~s}\end{array}$ & $\begin{array}{c}\text { odtłuszczanie ultradźwiękowe - Sur-Tec 134, } \\
\text { temperatura } 23^{\circ} \mathrm{C} \text {, czas } 180 \mathrm{~s}\end{array}$ \\
\hline 2. & płukanie - woda bieżąca, czas $60 \mathrm{~s}$ & płukanie - woda bieżąca, czas $60 \mathrm{~s}$ \\
\hline 3. & $\begin{array}{c}\text { dekapowanie }-5 \% \text { kwas siarkowy, } \\
\text { temperatura } 23^{\circ} \mathrm{C} \text {, czas } 60 \mathrm{~s}\end{array}$ & $\begin{array}{c}\text { dekapowanie }-5 \% \text { kwas siarkowy, } \\
\text { temperatura } 23^{\circ} \mathrm{C} \text {, czas } 60 \mathrm{~s}\end{array}$ \\
\hline 4. & płukanie - woda bieżąca, czas $60 \mathrm{~s}$ & płukanie - woda bieżąca, czas $60 \mathrm{~s}$ \\
\hline 5. & $\begin{array}{l}\text { aktywacja }-\mathrm{CrO}_{3} 250 \mathrm{~g} / \mathrm{dm}^{3}, \\
\text { temperatura } 65^{\circ} \mathrm{C} \text {, czas } 180 \mathrm{~s}\end{array}$ & $\begin{array}{c}\text { aktywacja }-\mathrm{CrO}_{3} 250 \mathrm{~g} / \mathrm{dm}^{3} \\
\text { temperatura } 65^{\circ} \mathrm{C}, \mathrm{czas} 180 \mathrm{~s}\end{array}$ \\
\hline 6. & płukanie - woda bieżąca, czas $180 \mathrm{~s}$ & płukanie - woda bieżąca, czas $180 \mathrm{~s}$ \\
\hline 7. & osuszanie - aceton & osuszanie - aceton \\
\hline 8. & $\begin{array}{l}\text { miedziowanie, temperatura } \\
25^{\circ} \mathrm{C}, 1,5 \mathrm{~A} / \mathrm{dm}^{2}, \text { czas } 8 \mathrm{~min}\end{array}$ & $\begin{array}{l}\text { miedziowanie, temperatura } \\
65^{\circ} \mathrm{C}, 2,5 \mathrm{~A} / \mathrm{dm}^{2} \text {, czas } 17 \mathrm{~min}\end{array}$ \\
\hline 9. & płukanie - woda bieżąca, czas 120 s & płukanie - woda bieżąca, czas 120 s \\
\hline 10. & suszenie - temperatura $60^{\circ} \mathrm{C}$, czas $240 \mathrm{~s}$ & suszenie - temperatura $60^{\circ} \mathrm{C}$, czas $240 \mathrm{~s}$ \\
\hline
\end{tabular}

Tablica III. Chropowatość powierzchni kompozytu grafitowego w zależności od sposobu obróbki powierzchni

Table III. The surface roughness of the graphite composite according to the method of surface treatment

\begin{tabular}{|c|c|c|c|c|c|}
\hline \multirow{2}{*}{ Lp. } & \multirow{2}{*}{ Materiał } & Obróbka powierzchni & \multicolumn{3}{|c|}{ Chropowatość powierzchni, $\boldsymbol{\mu m}$} \\
\cline { 4 - 6 } & \multirow{2}{*}{$\begin{array}{l}\text { kompozyt } \\
\text { grafitowy }\end{array}$} & obróbka strumieniowo-ścierna & $\mathbf{R a}$ & $\mathbf{R t}$ & $\mathbf{R z}$ \\
\cline { 4 - 6 } & szlifowanie & 0,44 & 4,46 & 3,37 \\
\hline 2. & grat & 13,91 & 96,54 & 67,51 \\
\hline
\end{tabular}
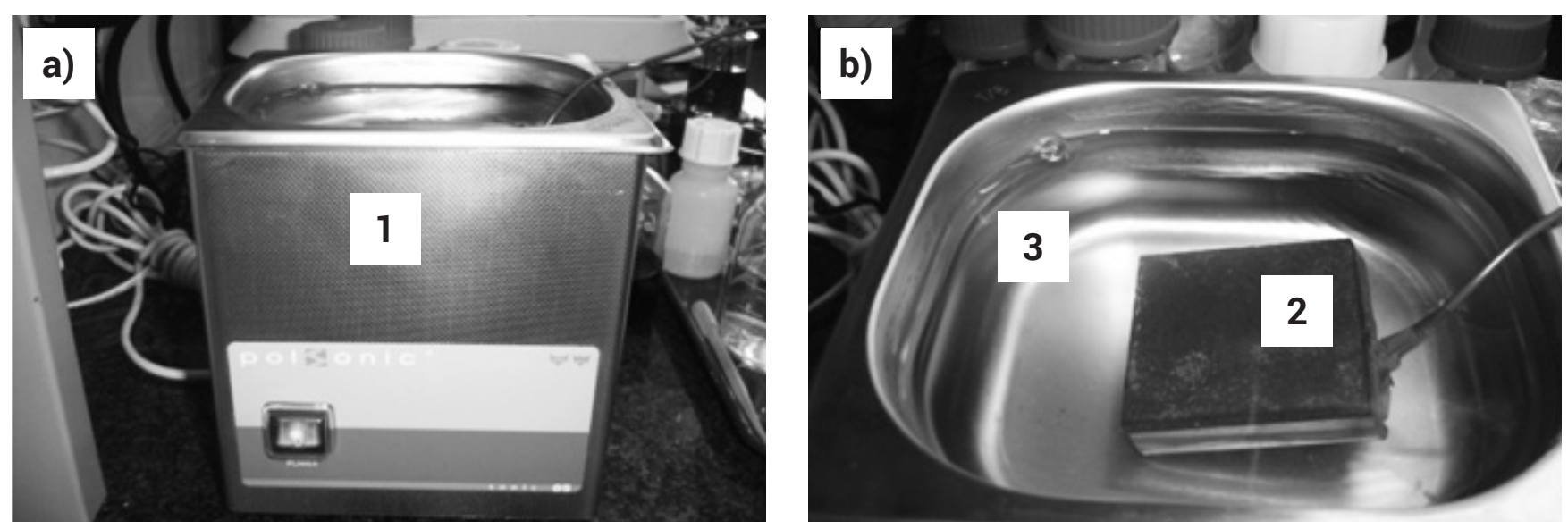

Rys. 3. Zestaw do czyszczenia ultradźwiękowego: 1 - myjka ultradźwiękowa, 2 - kompozyt grafitowy, 3 - kąpiel Sur-Tec 134 Fig. 3. Ultrasonic cleaning system: 1 - ultrasonic washer, 2 - graphite composite, 3 - Sur-Tec 134 bath

włoki Cu do podłoża, kompozyt grafitowy szlifowano papierem ściernym o gradacji 180 lub poddawano obróbce strumieniowo-ściernej przy użyciu korundu o granulacji ziaren $-45+5 \mu \mathrm{m}$. W tablicy III zestawiono wyniki pomiarów chropowatości powierzchni kompozytu grafitowego w zależności od sposobu jej przygotowania.

Przed pokrywaniem galwanicznym kompozytu bardzo ważne jest dokładne usunięcie pozostałości po obróbce mechanicznej. Osiągnięto to poprzez zastosowanie mycia ultradźwiękowego (rys. 3).

Wierzchnią warstwę kompozytu aktywowano w roztworze bezwodnika chromowego, płukano i poddano procesowi pokrywania (rys. 4).

Przykład naniesionej powłoki miedzianej, o grubości $5 \mu \mathrm{m}$, przedstawiono na rysunku 5.

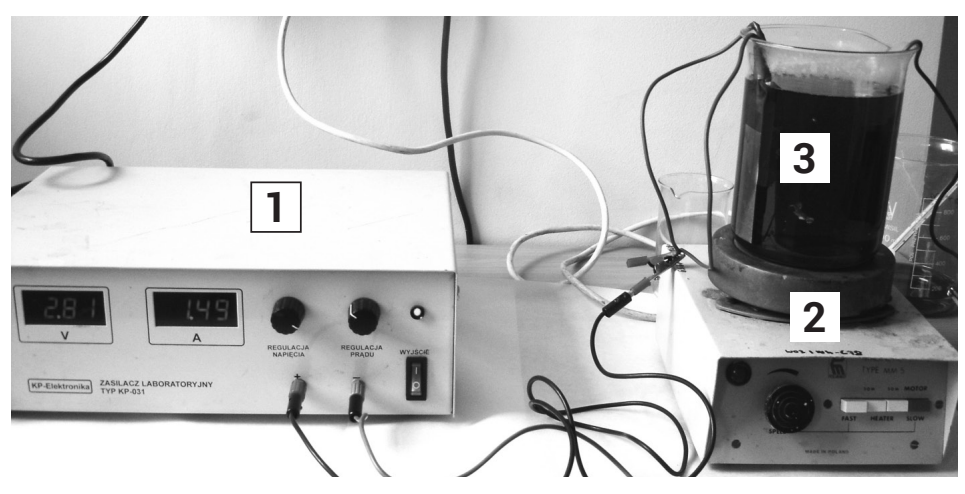

Rys. 4. Zestaw do nanoszenia galwanicznej powłoki miedziowej: 1 - prostownik, 2 - mieszadło magnetyczne z ogrzewaniem, 3 - elektrolizer Fig. 4. Galvanic coating of copper applying system: 1 - rectifier, 2 - magnetic stirrer with heating, 3 - electrolyzer 

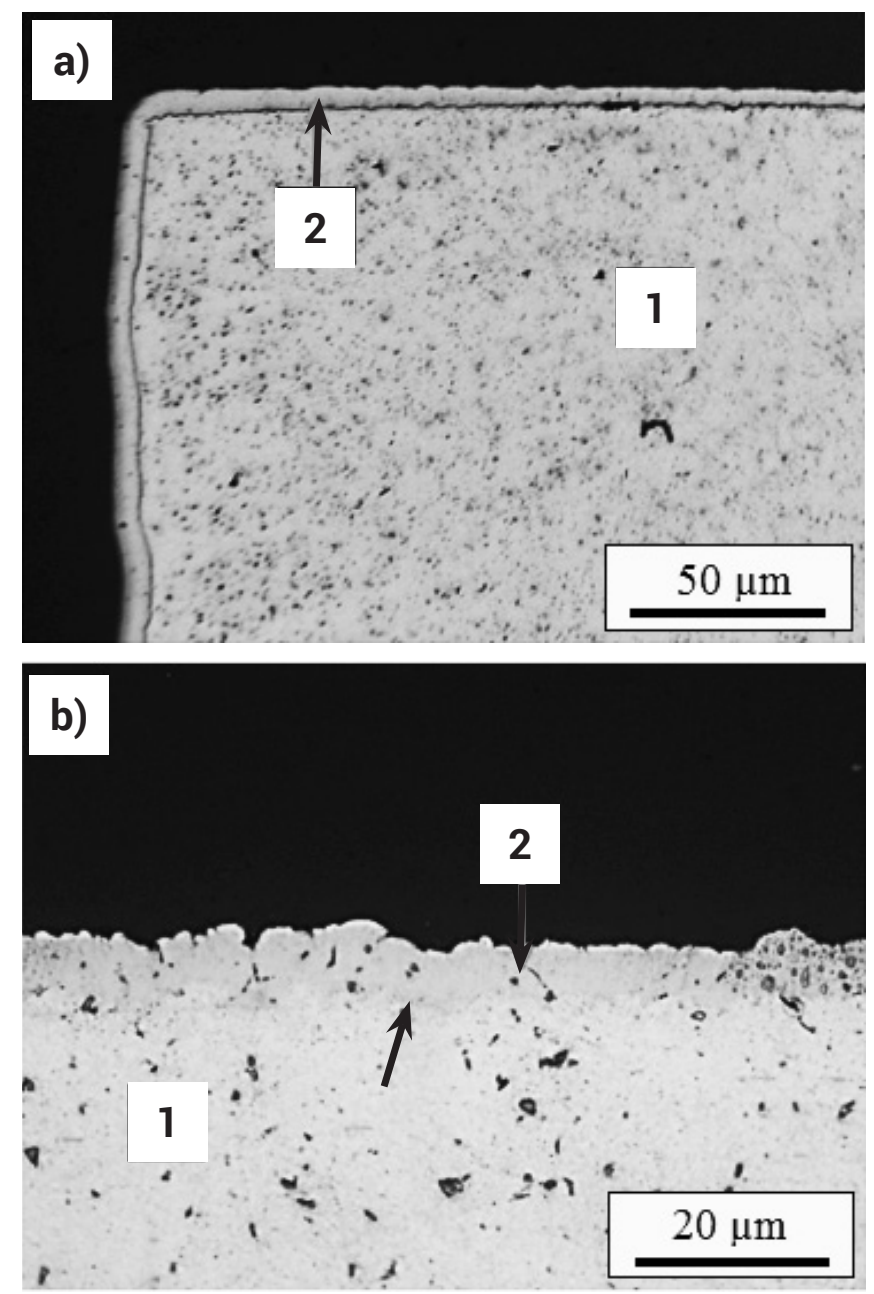

Rys. 5. Warstwa pośrednia Cu (2) naniesiona galwaniczne na kompozyt grafitowy (1)

Fig. 5. Cu intermediate layer (2) galvanically deposited on the composite graphite (1)

\section{Lutowanie miękkie stopu PA38 z kompozytem grafitowym}

Przed procesem lutowania stop aluminium poddano procesowi starzenia i dlatego temperatura procesu jego łączenia z kompozytem nie powinna przekraczać $200{ }^{\circ} \mathrm{C}$. W związku z tym do procesu lutowania dobrano lut cynowo-ołowiowy o oznaczeniu S-Sn60Pb40 (60\% wag. Sn i $40 \%$ wag. $\mathrm{Pb}$ ). Lut ten charakteryzuje się dobrą lutownością i temperaturą topnienia w zakresie $183 \div 190{ }^{\circ} \mathrm{C}(\mathrm{wg}$ PN-EN ISO 3677:200 i PN-EN ISO 9453:2008). W świetle wytycznych dyrektywy RoHS, stosowanej na terenie Unii Europejskiej od 1 lipca 2006 r., zabrania się stosowania niebezpiecznych substancji zawierających m.in. ołów. Jednakże wszędzie tam, gdzie nie jest jeszcze możliwe wyeliminowanie ołowiu, materiały z zawartością tego pierwiastka zostały dopuszczone do określonych zastosowań i nie podlegają restrykcjom dyrektywy RoHS.

W początkowych próbach lutowania miedziane warstwy pośrednie nanoszono galwanicznie na oba spajane materiały. Ponieważ przyczepność powłoki Cu do podłoża PA38 nie była zadowalająca, podjęto próbę lutowania kompozytu grafitowego pokrytego warstwą miedzi bezpośrednio z podłożem aluminiowym. Wymagało to jednak użycia odpowiednio aktywnego topnika. Dobór topnika jest tutaj bardzo istotny z punktu widzenia jakości i funkcjonalności połączenia lutowanego $[9,10]$. Zastosowano topnik o dużej aktywności chemicznej o handlowej nazwie Stay
Clean Aluminum Flux [5]. Temperatura jego aktywności zawiera się w zakresie $177 \div 288{ }^{\circ} \mathrm{C}$ [5]. Umożliwiło to pobielenie lutem S-Sn60Pb40 podłoża PA38 bez konieczności stosowania warstwy pośredniej. Takie rozwiązanie jest również korzystne ze względów ekonomicznych, ponieważ eliminuje konieczność nanoszenia na stop Al powłoki $\mathrm{Cu}$.

Podłoże aluminiowe przygotowano do procesu lutowania przez szlifowanie ręczne włókniną ścierną. Proces lutowania prowadzono w dwóch etapach. W pierwszym etapie pobielono spajane materiały przy użyciu kolby miedzianej ogrzewanej płomieniem propanowo-powietrznym. Etap drugi stanowił lutowanie właściwe, czyli połączenie ze sobą pobielonych próbek kompozytowych i aluminiowych w procesie lutowania płomieniem propanowo-powietrznym. W taki sposób przygotowano złącza lutowane do badań wytrzymałościowych i metalograficznych.

\section{Próby wytrzymałościowe}

Statyczną próbę wytrzymałości na ścinanie połączeń lutowanych (kompozyt grafitowy - aluminium PA38) przeprowadzono stosując maszynę wytrzymałościową o napędzie hydraulicznym, przy prędkości posuwu belki wynoszącej $0,2 \mathrm{~cm} / \mathrm{min}$ i zakresie pomiarowym do $10 \mathrm{kN}$. Przeprowadzono ją przy użyciu przyrządu, pokazanego na rysunku 6a, który umieszczano na kołysce wahliwej, zapewniającej osiowe obciążanie próbki. Na rysunku $6 \mathrm{~b}$ pokazano próbkę do statycznej próby ścinania. Złącze lutowane miało wymiary $12 \times 20 \mathrm{~mm}$.
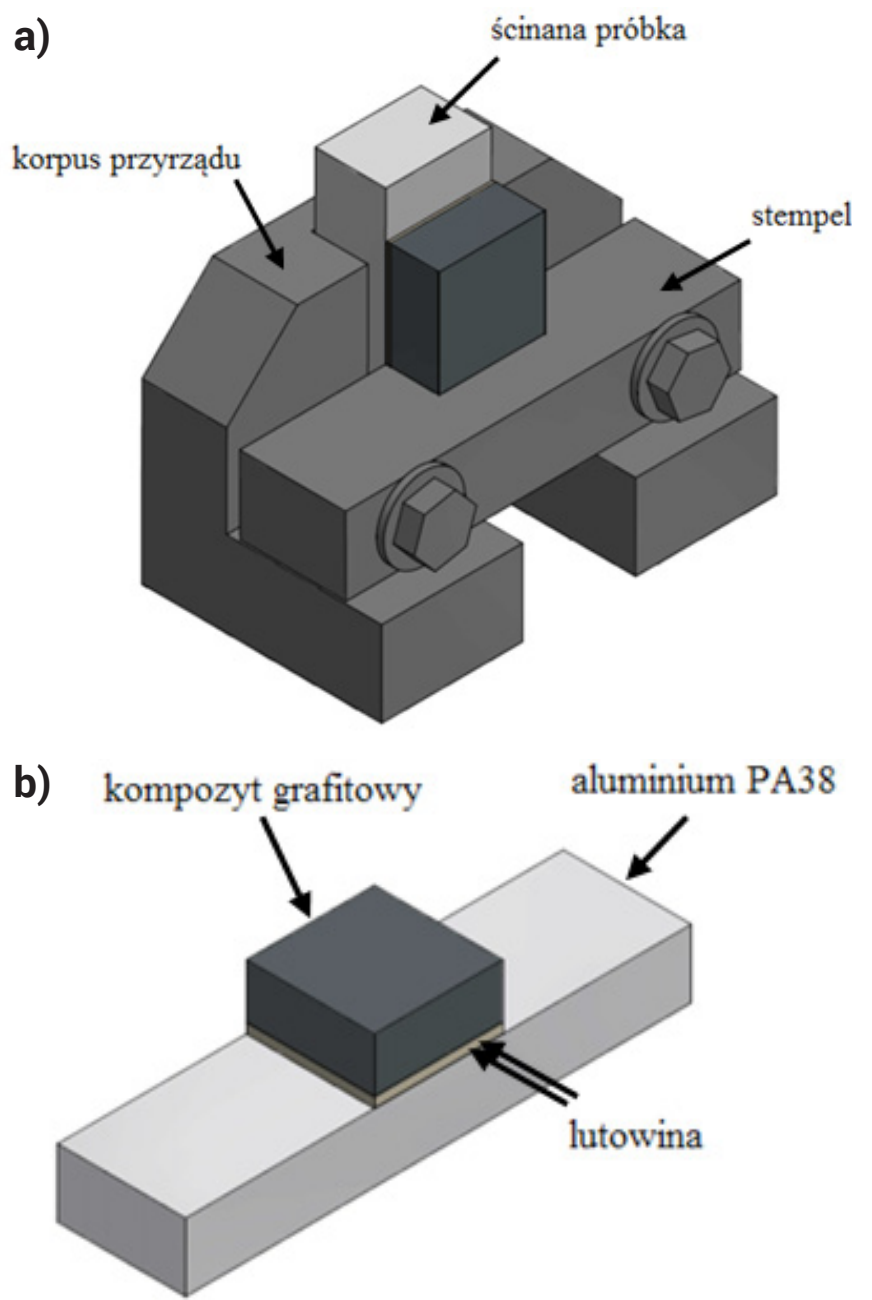

Rys. 6. Przyrząd do statycznej próby ścinania (a) i złącze lutowane kompozytu grafitowego $z$ aluminium PA38 (b)

Fig. 6. Device for static shear tests (a) and soldered joint the graphite composite with aluminum alloy PA38 (b) 
Na rysunku 7 pokazano szczegóły techniczne procesu ścinania połączenia lutowanego w przyrządzie, między płytami dociskowymi maszyny wytrzymałościowej.

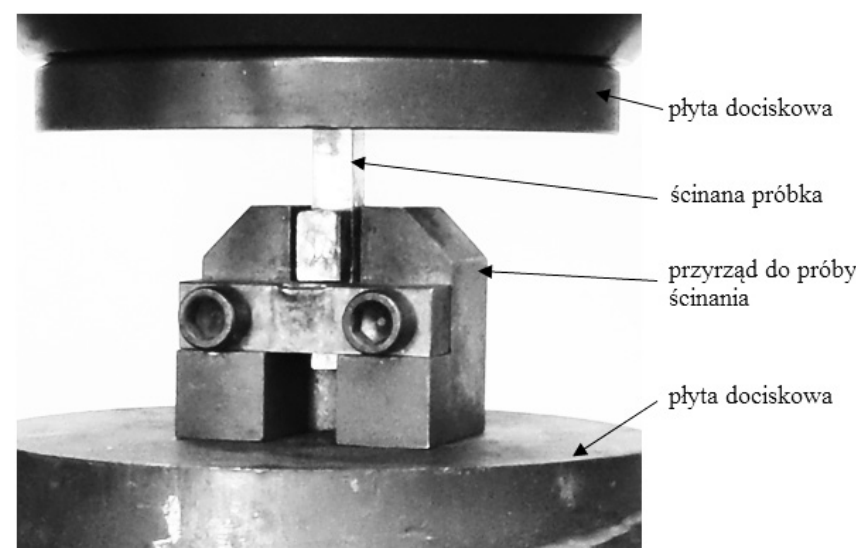

Rys. 7. Statyczna próba ścinania połączeń lutowanych kompozyt grafitowy - aluminium

Fig. 7. Static shear test of graphite composite - aluminum soldered joints

Do statycznej próby ścinania przygotowano po 3 połączenia lutowane dla każdej z metod przygotowania powierzchni kompozytu grafitowego, przed naniesieniem warstwy pośredniej Cu. W tablicy IV zestawiono wyniki pomiarów otrzymane w statycznej próbie ścinania.

Tablica IV. Wyniki statycznej próby ścinania połączeń kompozytu grafitowego ze stopem aluminium PA38

Table IV. Results of static shear tests graphite composite with aluminum alloy PA38 joints

\begin{tabular}{|c|c|c|c|}
\hline \multirow{2}{*}{ Lp. } & \multirow{2}{*}{$\begin{array}{l}\text { Przygotowanie } \\
\text { powierzchni }\end{array}$} & \multicolumn{2}{|c|}{ Wytrzymałość na ścinanie } \\
\hline & & $R_{t}[\mathrm{MPa}]$ & $\mathbf{R}_{\mathrm{t} \text { tsr }}[\mathrm{MPa}]$ \\
\hline 1. & \multirow{3}{*}{ szlifowanie } & 6,4 & \multirow{3}{*}{6,3} \\
\hline 2. & & 5,8 & \\
\hline 3. & & 6,6 & \\
\hline 4. & \multirow{3}{*}{$\begin{array}{l}\text { obróbka } \\
\text { strumieniowo- } \\
\text {-ścierna }\end{array}$} & 12,7 & \multirow{3}{*}{12,5} \\
\hline 5. & & 12,0 & \\
\hline 6. & & 12,4 & \\
\hline
\end{tabular}

Jak wynika z analizy danych zamieszczonych w tablicy IV, odpowiednie przygotowanie podłoża kompozytu grafitowego przed nałożeniem warstwy pośredniej $\mathrm{Cu}$ ma duży wpływ na wytrzymałość mechaniczną badanych połączeń lutowanych. Zastosowanie obróbki strumieniowo-ściernej umożliwia dwukrotne zwiększenie wytrzymałości na ścinanie złączy lutowanych. Niezależnie jednak od sposobu przygotowania powierzchni mechanizm zniszczenia złącza każdorazowo miał charakter adhezyjny (rys. 8) i występował na granicy połączenia kompozytu grafitowego z galwaniczną powłoką Cu.

Obróbka strumieniowo-ścierna zapewnia zatem lepsze rozwinięcie powierzchni kompozytu grafitowego, umożliwiając podczas galwanizacji „zakotwiczanie się” cząsteczek Cu w powstałych nierównościach, przez co jej przyczepność do podłoża jest większa, a tym samym wzrasta wytrzymałość złączy lutowanych.

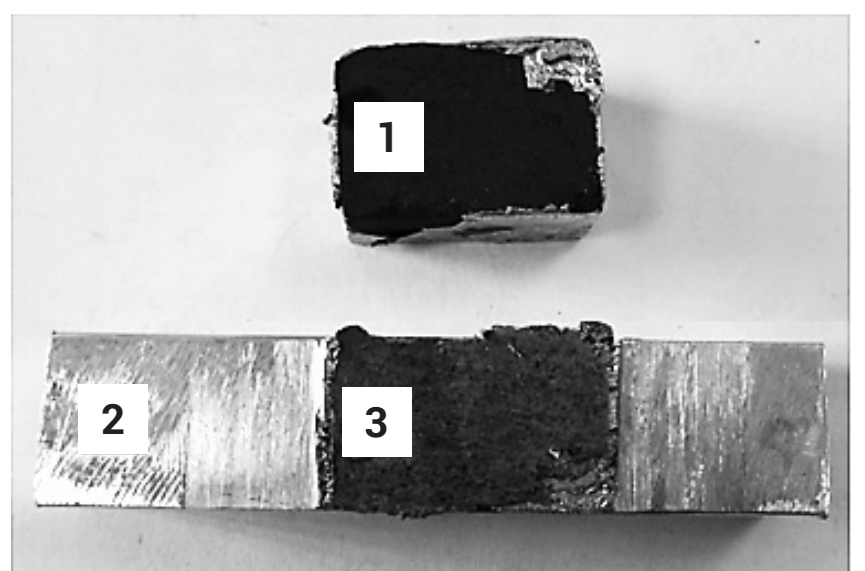

Rys. 8. Przykładowy złom połączenia lutowanego po próbie ścinania; 1 - kompozyt grafitowy przygotowany przez szlifowanie, 2 - stop aluminium PA38, 3 - warstwa $\mathrm{Cu}$

Fig. 8. Example of scrap soldered joint after shear tests; 1 - graphite composite prepared by grinding, 2 - aluminum alloy PA38, 3 - Cu layer

\section{Badania metalograficzne złączy lutowanych}

Badania metalograficzne przeprowadzono na poprzecznym przekroju próbek polutowanych i zainkludowanych w żywicy epoksydowej, szlifując je na wodnych papierach ściernych SiC do gradacji 2400 i polerując tlenkiem glinu o wielkości ziarna 0,3 $\mu \mathrm{m}$. Tak przygotowane próbki metalograficzne obserwowano przy użyciu mikroskopu świetlnego firmy Olympus, model CA25, sprzężonego $\mathrm{z}$ aparatem cyfrowym CAMEDIA C3030 i systemem archiwizacji obrazu.

$\mathrm{Na}$ rysunku 9 pokazano przekrój złącza lutowanego kompozytu grafitowego $z$ aluminium PA38 wykonanego przy użyciu lutu S-Sn60Pb40. Szczelina lutownicza, o szerokości 0,2 mm, jest na całej długości złącza wypełniona lutem.

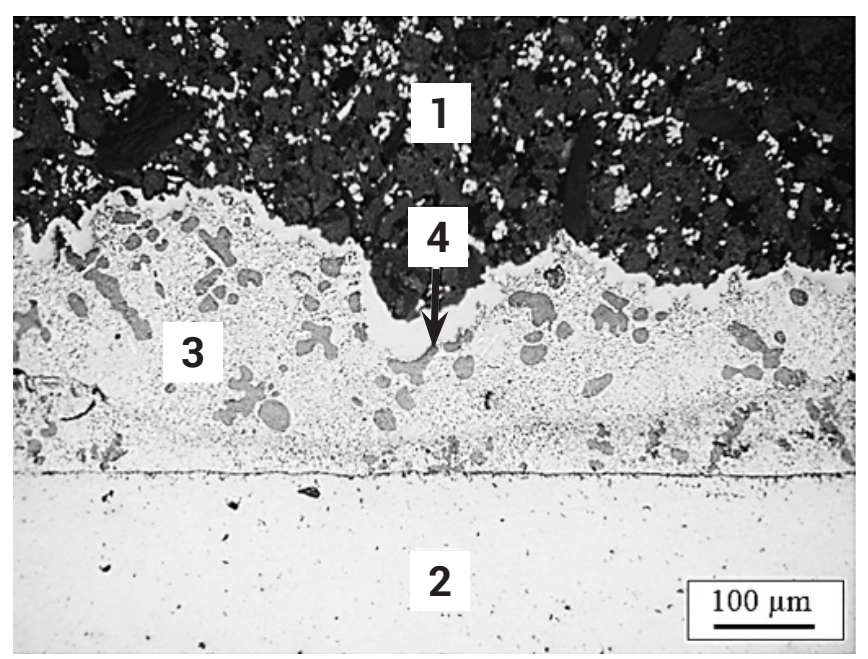

Rys. 9. Mikrostruktura połączenia lutowanego: 1 - kompozyt grafitowy z napełniaczem $\mathrm{Cu}, 2$ - stop aluminium PA38, 3 - lutowina, 4 - warstwa $\mathrm{Cu}$

Fig. 9. Microstructure of soldered joints: 1 - graphite composite with Cu filler, 2 - aluminum alloy PA38, 3 - solder, 4 - Cu layer

$\mathrm{Na}$ rysunku 10 a widoczna jest mikrostruktura złącza pokazana od strony kompozytu grafitowego oraz od strony stopu aluminium PA38 (rys. 10b). W strukturze lutowiny występują dendryty roztworu stałego $\beta$ oraz drobnoziarnista eutektyka $a+\beta$ rozmieszczona w przestrzeniach międzydendrytycznych. 

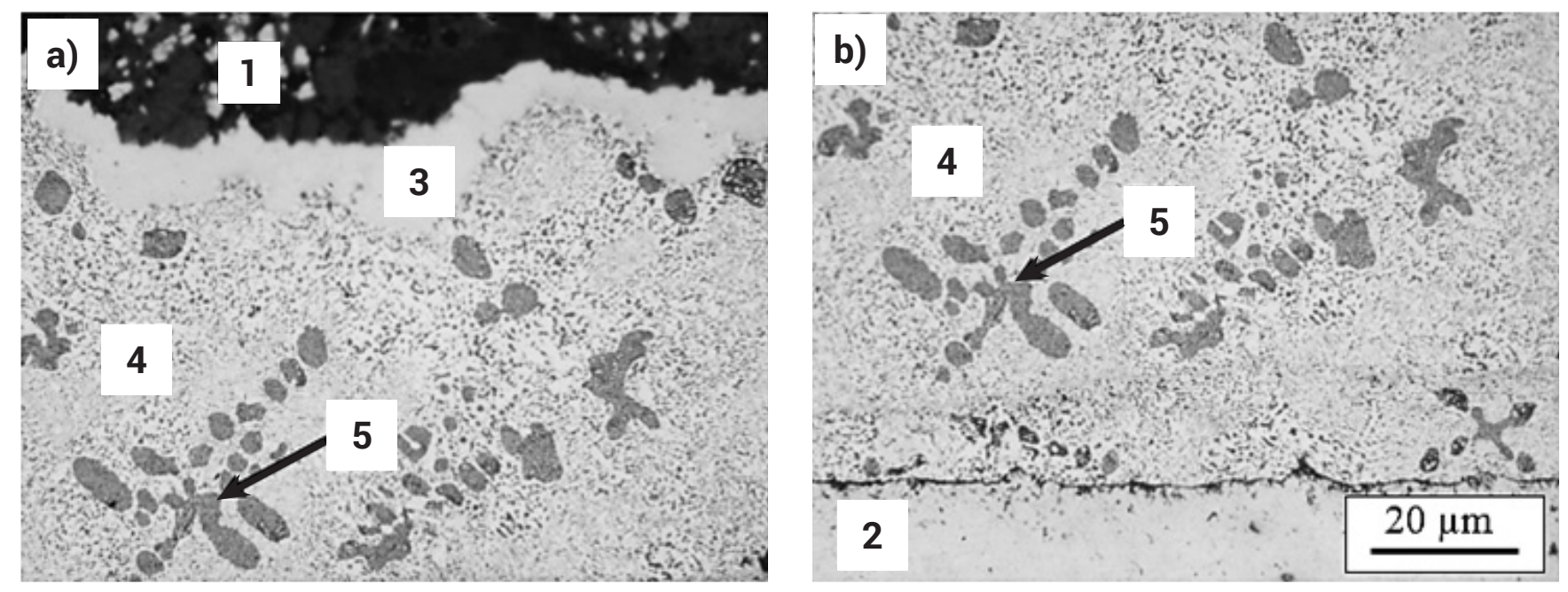

Rys. 10. Mikrostruktura połączenia lutowanego: widok od strony kompozytu grafitowego (a) i od strony aluminium PA38 (b); 1 - kompozyt grafitowy, 2 - stop aluminium PA38, 3 - warstwa $\mathrm{Cu}, 4$ - eutektyka $\alpha+\beta, 5$ - dendryty roztworu stałego $\beta$

Fig. 10. Microstructure of soldered joint: a view from the side of graphite composite (a) and from the aluminum alloy PA38 (b); 1 - graphite composite 2 - aluminum alloy PA38, 3 - Cu layer, 4 - eutectic $a+\beta, 5$ - dendrites of solid solution $\beta$

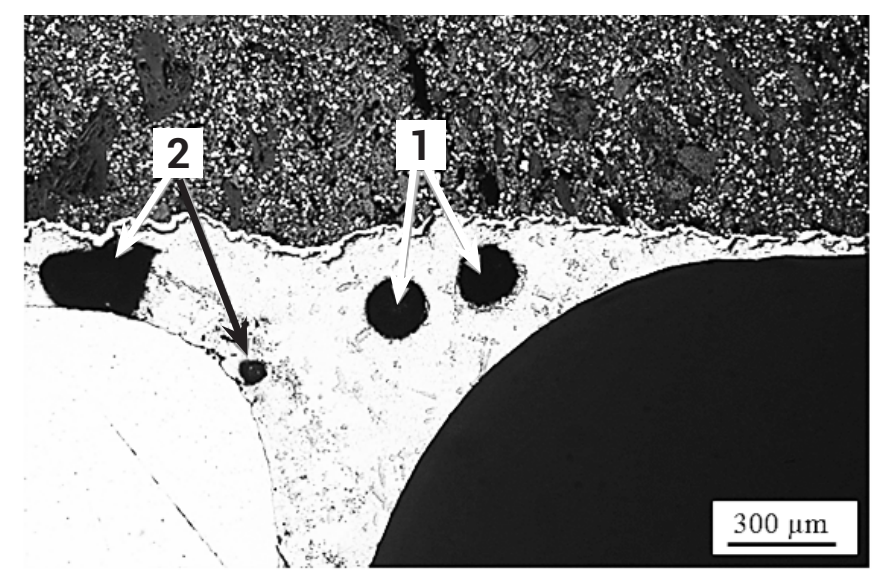

Niezgodności lutownicze w postaci pęcherzy gazowych oraz pozostałości topnika występują jedynie na jednym z końców połączenia (rys. 11). Są to typowe niezgodności, które często występują w procesie lutowania topnikowego. Ich ilość i miejsce występowania w omawianym przypadku nie mają jednak istotnego wpływu na funkcjonalność połączenia lutowanego.

\section{Wnioski}

Na podstawie wyników przeprowadzonych badań sformułować można następujące wnioski:

- wytworzenie dobrej jakości połączeń kompozytu grafitowego ze stopem aluminium PA38 metodą lutowania miękkiego wymaga zastosowania warstwy pośredniej Cu o grubości ok. $5 \mu \mathrm{m}$ naniesionej galwanicznie na podłoże grafitowe;

- użycie topnika o dużej aktywności chemicznej umożliwia bezpośrednie pobielanie stopu PA38 lutem Sn-Pb, bez konieczności nanoszenia miedzianej warstwy pośredniczącej;

- decydujący wpływ, na wytrzymałość poddanych badaniom połączeń lutowanych, ma sposób przygotowania podłoża kompozytu grafitowego do procesu galwanicznego nanoszenia powłoki Cu. Zastosowanie obróbki strumieniowo-ściernej powierzchni umożliwia dwukrotny wzrost wytrzymałości na ścinanie złączy lutowanych w porównaniu z podłożem szlifowanym;

- charakterystyczne dla lutowania topnikowego niezgodności w postaci pęcherzy gazowych są akceptowalne dla rozwiązań konstrukcyjnych złączy o dużej powierzchni, pod warunkiem ich niewielkich wymiarów, dopuszczalnej ilości i równomiernego rozmieszczenia w całej objętości.

\section{Literatura}

[1] Mirski Z., Granat K., Prasałek A.: The diffusive barriers in copper brazing with austenitic steel by use the Cu-Ag-P (L-Ag15P) filler metal, The Archives Metallurgy and Materials, tom 53, nr 4/2008, s. 1035-1046.

[2] Mirski Z., Wojdat T., Piwowarczyk T., Stachowicz M.: Bariery dyfuzyjne zapobiegające kruchości połączeń lutowanych aluminium z innymi metalami, Przegląd Spawalnictwa, nr 8/2013

[3] Mirski Z., Wojdat T., Stachowicz M.: Soldering of aluminium with copper and steel using intermediate layer $\mathrm{Zn}-\mathrm{Ni}$, Archives of Civil and Mechanical Engineering, 2015, vol. 15, nr 4, s. 903-910.

[4] Wojdat T., Winnicki M., Rutkowska-Gorczyca M., Mirski Z., Ambroziak A.: Zastosowanie warstw pośrednich nanoszonych różnymi metodami natryskiwania cieplnego do lutowania miękkiego aluminium z miedzią, Przegląd Elektrotechniczny, nr 3/2015, s. 90-94.

[5] Poradnik lutowania twardego i miękkiego, katalog firmowy Harris Calorific International Sp. z o.o, Dzierżoniów 2016.

[6] Praca zbiorowa: Poradnik galwanotechnika, WNT, Warszawa 2002.

[7] Dylewski R., Gnot W., Gonet M.: Elektrochemia przemysłowa. Wybrane procesy i zagadnienia, Wyd. Politechniki Śląskiej. Gliwice 1999.

[8] Jansen R., Preikschat P., Opper M.: Cyanidefreie alkalische kupferelektrolyte, Galvanotechnik 73 (1998).

[9] Piwowarczyk T., Harapińska E., Wojdat T.: Trendy rozwojowe technologii lutowania i metod kontrolnych, Przegląd Spawalnictwa, nr 9/2016.

[10] Ambroziak A., Białucki P., Derlukiewicz W., Lange A.: Własności aluminiowych złączy wykonanych spoiwami na osnowie cynku, Przegląd Spawalnictwa, $\mathrm{nr}$ 9/2016. 